Araştırma Makalesi

(Research Article)

Münevver TiRYAKIOĞLU LIGVANI

Metin ARTUKOĞLU

Ege Üniversitesi, Ziraat Fakültesi, Tarım Ekonomisi Bölümü, 35100 İzmir/Türkiye

e-posta: metin.artukoglu@ege.edu.tr

\section{Anahtar Sözcükler:}

Zeytin, sofralık zeytin üretimi, sofralık

zeytin pazarlaması, sofralık zeytin

işletmeleri

\section{Key Words:}

Olive, table olive production, table olive marketing, table olive enterprises

\title{
Sofralık Zeytin Üretimi, Pazarlaması, Sorunlar ve Çözüm Önerileri: Akhisar İlçesi Örneği ${ }^{1}$
}

\author{
A Research on Table Olive Production, Marketing, Problems \\ and Solutions: The Case of Akhisar
}

${ }^{1}$ Bu çalışma ilk yazarın Yüksek Lisans tezinin bir kısmından özetlenmiştir.

Alınış (Received):17.02.2015 Kabul tarihi (Accepted): 11.03.2015

\section{ÖZET}

ürkiye sofralık zeytin üretimi ve ihracatı konusunda önemli bir potansiyele sahiptir. Ancak üretiminden kaynaklanan sorunlar ve pazarlama stratejisindeki eksiklikler nedeniyle, bu potansiyel istenilen şekilde değerlendirememektedir. Bu çalışmada, Akhisar bölgesindeki sofralık zeytin işletmeleri örneğinden hareket edilerek; sofralık zeytinin üretim ve pazarlama yapısı ortaya konulmuş, sorunları belirlenmiş ve çözüm önerileri getirilmiştir. Sofralık zeytin işletmelerinin temelini küçük kapasiteli aile işletmelerinin oluşturması, alt yapının yetersizliği ve mevcut alt yapıda istenilen nitelikte üretim yapılmaması nedeni ile bu sektör istenilen gelişmeyi gösterememiştir. Bu çalışma ile getirilen önerilerin bu alanda politika belirleyicilere önemli ipuçları verebileceği düşünülmektedir.

\begin{abstract}
Curkey, has an important potential for the table olive production and exports. However, a number of problems due to lack of production and marketing strategies; mentioned potential cannot be benefited from the desired manner. In this study, with the enterprise of table olives in Akhisar survey of businesses by the current situation in the region, foreign market potentials and problems have been identified and suggested solutions. Not only because small family businesses form the basis of table olive enterprises, but also the lack of the infrastructure caused the quality of the product to be unable to reach the desired level. Recommendations brought with this study are considered to give important clues to policy makers regarding this area.
\end{abstract}

\section{Gíriş}

Zeytin yetiştiriciliği dünyada yaklaşık 10 milyon ha alanda yapılmaktadır. Dane zeytin üretim miktarı dünyada toplam 20 milyon tondur. Önemli zeytin üreticileri sırasıyla İspanya, İtalya, Yunanistan, Tunus, Türkiye, Fas ve Suriye'dir (Özkaya, vd.2015). 2013/ 2014 üretim sezonu verileri ile, üretilen sofralık zeytin miktarı 2.6 milyon ton olup, Türkiye üretimi 430 bin ton civarındadır (UZK,2014).

Bu çalışmanın birincil amacı; Türkiye'de üretilen sofralık zeytinin pazarlama durumun tespiti, pazardaki sorunların belirlenmesi ve potansiyel sofralık zeytin pazarlarının araştırımasına dayanmaktadır. Bu bağlamda, sektörde uygulanan pazarlama stratejileri, dağıtım kanalları, sektörün gelişmesi, ihracattaki payının arttıııması konuları da incelenmiş̧ir.

\section{MATERYAL ve YÖNTEM}

\section{Materyal}

Çalışmanın ana materyali başlıca iki kaynaktan derlenmiştir. Birinci grup kaynaklar, FAO (Food and Agriculture Organization of the United Nations), IOC (International Olive Council), TÜIK (Türkiye İstatistik Kurumu), Zeytincilik Araştırma İstasyonu verileri ve 
yayınları, Ege Zeytin ve Zeytinyağı İhracatçı Birlikleri, Zeytin ve Zeytinyağı Tarım Satış Kooperatifleri Birliği (TARiş) verileri, farklı kurumların raporlarından oluşmaktadır. Ayrıca, konuyla ilgili yapılmış çeşitli araştırmaların sonuçlarından da yararlanılmıştır.

İkinci grup materyaller, arazi gözlemleri ve Akhisar da yer alan sofralık zeytin işletmeleri ve ihracatçılarla yapılan görüşmelerden oluşmaktadır. Bu grup içerisinde; Manisa Tarım İl Müdürlüğü verileri, Akhisar Tarım İlçe Müdürlüğü verileri, Akhisar Aktif İşadamları Derneği (AKIAD), Akhisar Ziraat Odası, Akhisar Ticaret Borsası, Akhisar Ticaret ve Sanayi Odası kayıtları da vardır.

Araştırmanın verileri makro ölçekte genellikle 2000 yılı ve sonrasını, mikro verilerde ise Akhisar ilçesinde faaliyet gösteren sofralık zeytin işleme tesisleri yöneticilerinden elde edilen 2008/2009 ve 2009/2010 üretim sezonu verilerden oluşmaktadır.

\section{Yöntem}

\section{Araştırma Alanının Seçiminde İzlenen Yöntem}

Araştırmanın sahaya dönük çalışması için Manisa İli Akhisar İlçesi seçilmiştir. Akhisar ilçesinin seçilmesinin nedeni, Akhisar ilçesinin Manisa ili içerisinde önemli bir zeytin üretim potansiyeline sahip olması ve üretimin önemli bir kısmı sofralık olarak değerlendirilmesi, bölgede önemli sayıda işletme bulunması ve son yıllarda marka olma yolundaki aktif çalışmalarıdır. İlçenin 827.635 dekarlık tarımsal arazisinin \% 48'lik bölümü zeytine ayrılmıştır (Güner ve ark, 2010).
Akhisar'da üretilen yıllık ortalama 200.000 ton zeytinin, 130.000 tonu sofralık olarak değerlendirilirken, yağlık olarak ayrılan 70.000 ton zeytinden yaklaşık olarak 15.000 ton zeytinyağı elde edilmektedir. Ayrıca Akhisar'da Gemlik, Ayvalık, Uslu ve Domat olmak üzere 4 zeytin çeşidinin üretimi yaygındır (Anonim, 2009). Akhisar, Türkiye sofralık siyah zeytinin üretiminin \% 35'i ile, yeşil zeytin olan domat'ın \% 80'ini üretmektedir (Kayalı ve ark, 2008).

Akhisar Ticaret ve Sanayi Odası'na kayıtlı 1600 kadar işletmenin, yaklaşık 1/5'ini zeytin üzerine çalışan işletmeler oluşturmaktadır. İlçede 300' e yakın zeytin işleme tesisi bulunmaktadır. İşletmelerde yaklaşık 3.000 kişiye sürekli istihdam sağlarken, mevsimlik işçilerle birlikte bu sayı 5.000'ni aşmaktadır. Bölgede üretilen zeytinlerin büyük bölümü iç piyasaya verilirken, ihracata yönelik çalışan firmaların esas pazarını ise Romanya ve Bulgaristan oluşturmaktadır (Anonim, 2010).

\section{Sofralık Zeytin İşleme Tesislerinin Seçiminde İzlenen Yöntem}

Anket yapılacak işletmelerin belirlenmesi amacıyla Akhisar Ticaret Odası ve Akhisar Tarım İlçe Müdürlüğüne gidilerek, işletmelerin listesi elde edilmeye çalışılmış ve yapılan tespitler sonucunda, 300 civarında işletmenin bulunduğu görülmüştür. Daha sonra veri teminin sağlıklı olamayacağı ilgili kurumlarca belirtilen 60 işletme liste dışı bırakılarak, kalan 240 işletme arasından oransal örnekleme formülüyle örnek hacmi belirlenmiştir (Newbold, 1995).

$\mathbf{n}=$ örnek hacmi

$$
n=\frac{N p(1-p)}{(N-1) \sigma_{\hat{p}_{x}}^{2}+p(1-p)}
$$

$\mathbf{N}=$ Ana kitle

p= Örneğe girebilecek istenen özelliği taşıyan işletmelerin ana kitledeki işletme sayısına oranını göstermektedir. Maksimum örnek hacmine ulaşmak için $p=0.5$ alınmıştır.

Güven aralığı : \% 90

Hata payı : :\%14

Yapılan hesaplama sonucunda 31 işletme ile görüşülmesine karar verilmiştir. İşletmelerden gerekli bilgilerin alınması amacıyla bir anket formu oluşturulmuştur. Bu formda işletmelerin üretim kapasitesi ve üretim kaynakları ile ilgili sorular olduğu kadar, dış ticaret potansiyelleri ve işlenen zeytinlerin dış pazarda pazarlanabilme potansiyelleri ( ürün çeşitleri, üretim prosesleri, ambalaj vb. özellikleri bakımından) ve ticari ilişkileri de ayrıntılı olarak incelenmiştir.

\section{Verilerin Analizinde İzlenen Yöntem}

Makro verilerin analizinde çoğunlukla yüzde hesaplamaları ve grafik gösterimlerinden yararlanılırken, mikro verilerin analizinde ise bu yönteme ilave olarak, $5^{\prime}$ li likert ölçeğinden yararlanılmıştır.

\section{Türkiye'de Sofralık Zeytin Üretimi ve Pazarlaması}

Türkiye'de 400.000 çiftçi ailesi ve her aile ortalama beş kişi kabul edildiğinde, yaklaşık 2.000.000 kişi 
geçimini doğrudan zeytincilikten sağlamaktadır. Türkiye, dünya zeytin alan varlığının \% 8,1'ine, üretiminin \%8,2'sine sahiptir (FAO,2014). Türkiye'de zeytin alanları, 2000 yılından sonra devlet tarafından verilen sertifikalı fidan ve bahçe tesisi desteği ile 200-2013 döneminde \% 37.6 artmıştır (Gıda Tarım ve Hayvancılık Bakanlığı, 2014).

Türkiye'de bölgeler bazında bir değerlendirme yapıldığında, Ege Bölgesinde, zeytin üretiminin \%20'si Marmara bölgesinde \%90'ı, Akdeniz Bölgesinde ise, \% 32'si sofralık olarak değerlendirilmektedir. Türkiye'nin toplam sofralık zeytin üretiminin \%40'ı Marmara bölgesinde gerçekleşmektedir (ZZTK,2015)..

Türkiye, sofralık zeytin üretimi ve işlemesinde uzun bir geleneğe sahip olmasına rağmen, bu sektör son 70 yıl içerisinde önemli bir endüstriyel gelişim göstermiştir. Günümüzde, Türkiye sofralık zeytinde dünyada önemli bir üretici ve tüketici konumundadır (UZZK, 2010).

Türkiye de sofralık zeytin işletmelerinin temelini, küçük kapasiteli çok sayıda aile işletmeleri oluşturmaktadır. Altyapının yetersizliği, istenilen kalitede üretim yapılmasını ve verimliliği sınırlamaktadır. Gıda Tarım ve Hayvancılık Bakanlığı gıda sicil verilerine göre, ülkemizde sofralık zeytin işleyen 823 adet tesis bulunmaktadır. Bu tesislerde üretilen toplam 3721 ürün çeşidi için üretim izin sertifikası düzenlenmiştir (TBMM, 2008).

Bunların \% 10'u özel şirketler, \% 10'u kooperatifler ve geri kalan \% 80'i küçük aile işletmeleridir. Sınırlı sayıda olmalarına rağmen, kooperatifler özellikle Marmarabirlik sofralık zeytin pazarlamasında önemli bir rol oynamaktadır. Marmarabirlik, Türk sofralık zeytin üreticilerinin \% 50'sinden fazlasını bir araya getirmektedir; Ege Bölgesi'nde daha çok yağ sektöründe faaliyet gösteren Tariş'inde, son yıllarda sofralık zeytin sektörüne hissedilir bir etkisi bulunmaktadır (UZZK, 2010). (Şekil 1)

Türkiye'de üretilen 200 bin ton sofralık zeytinin ancak \% 25'i ihraç edilmekte, geri kalanı iç tüketime ayrılmaktadır (Özkaya vd, 2010). Genel olarak incelendiğinde, dünya ve $A B$ sofralık zeytin ihracatının arttığı görülmektedir. 2012/2013 sezonu verileriyle dünya ihracatında $A B^{\prime}$ nin payı \% 43.8, Türkiye'nin payı ise \% 10'dur (Gümrük ve Ticaret Bakanlığı,2014).

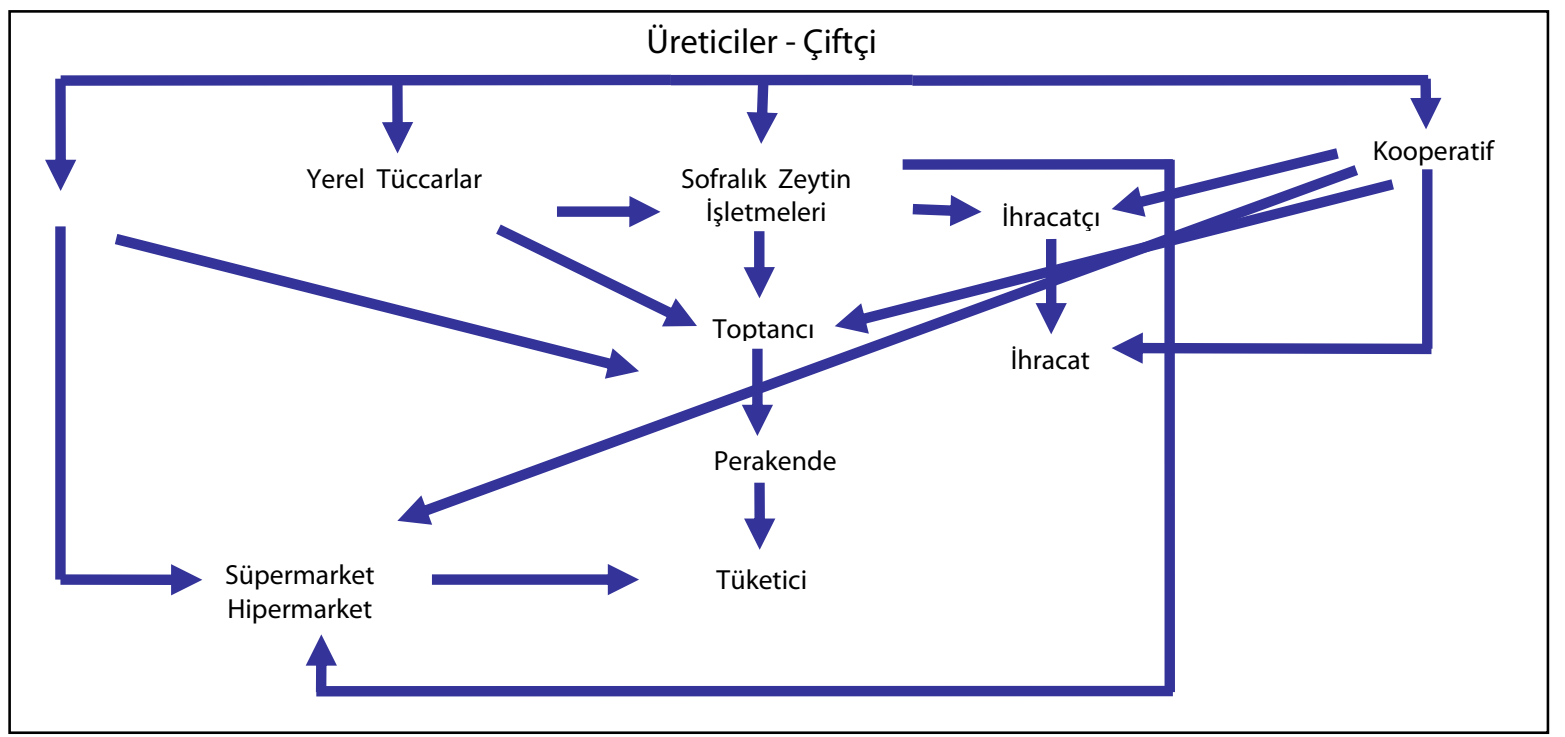

Şekil 1.Türkiye de sofralık zeytin pazarlama kanalı

Figure 1. Table olive marketing channel in Turkey

\section{Akhisar İlçesi Örneğinde Sofralık Zeytin Üretimi ve Pazarlaması \\ Zeytin İşletmeleri ve Yöneticilerinin Genel Özellikleri \\ İncelenen Sofralık Zeytin işletmelerinin \% 16,12' inin şahıs işletmesi ve \% 83,87'inin Limited Şirket olduğu belirlenmiştir.}

İşletmelerin sektörde faaliyet gösterme süreleri ortalaması 20.41 yıldır. Yapılan anket çalışmalarında, işletmelerin bazıları faaliyete geçme süreleri yeni gibi görünse de, ailede zeytincilik faaliyetinin eskiye dayandığı gözlemlenmiştir. Sofralık zeytin işletmelerinin \% 92.25'ni yerli sermayeli, \% 7.74'nünün yabancı sermayeli olduğu görülmektedir. Tamamı yabancı 
sermayeli işletmelerin oranı \% 6.5'dir. Sofralık zeytin işletmelerinin \% 93.5 'inde çalışan üst yönetimin aile bireylerinden oluştuğu \% 6.5'inde ise aile bireyleri dışında yöneticilerin de yönetimde bulunduğu gözlemlenmiştir.

Sofralık zeytin işletmelerinde üretim için mühendis veya teknisyen istihdamının çok yaygın olmadığı görülmektedir. Söz konusu sofralık zeytin işletmelerindeki mevsimlik işçilerin yıllık ortalama 4 ay çalıştıkları, diğerlerinin daimi personel oldukları görülmektedir.

Sofralık zeytin işletmelerinin; \% 12.9 u ihracatçı, \% 9.67 si toptan ürün alıp, ihracatçı, \% 61.29'nun işleyici ve ihracatçı, \% 6.45'nin işleyici-ithalatçı-ihracatçı olduğu ve \% 9.67'sininde sadece işleyici olduğu belirlenmiştir. İşletmelerin büyük çoğunluğu $(\% 67,74)$ devlet desteklerinden yararlanmamıştır. Yararlananların destekler ise kırsal kalkınma projeleri $(\% 9,7)$ ve KOSGEB $(\% 9,7)$ şeklinde belirtilmiştir.

Sofralık zeytin işletmelerinin yöneticilerinin eğitim durumlarına baktığımızda; \% 74.2'sinin üniversite, \% 25.8'nin orta dereceli okul (lise ve eski adıyla ortaokul gibi) mezunu olduğu saptanmıştır. Yöneticilerin yaşlarına bakıldığında; yöneticilerin yaşının 29 ila 56 arasında değiştiği ve yaş ortalamasının 36 olduğu görülmüştür. Yöneticilerin sektördeki deneyimleri ortalama 10 yıldır.

\section{Zeytin İşletmelerinde Zeytin Tedariki ve Kapasite Kullanım Durumu}

Sofralık zeytin işletmelerinin genellikle \% 35.5 oranda Uslu ve Gemlik zeytini işlemekte, bunu \% 19.4 ile Uslu, Ayvalık, Gemlik, Tekir ve Domat zeytin çeşidi işleyen işletmeler ve \% 19.3 ile Uslu, Ayvalık, Gemlik, Memecik ve Domat işleyen işletmeler takip etmektedir. Uslu ve Gemlik çeşidi zeytin işleyenlerin oranı \% 16.1, Memecik ve Ayvalık işleyenlerin oranı \% 6.5 ve \% 3.2 si işletmesinde sadece Gemlik çeşidi zeytin işlemekte olduğu saptanmıştır. Sofralık Zeytin işletmeleri işledikleri zeytinin önemli ölçüde kısmını üreticilerden doğrudan karşılamaktadırlar (Şekil 2).

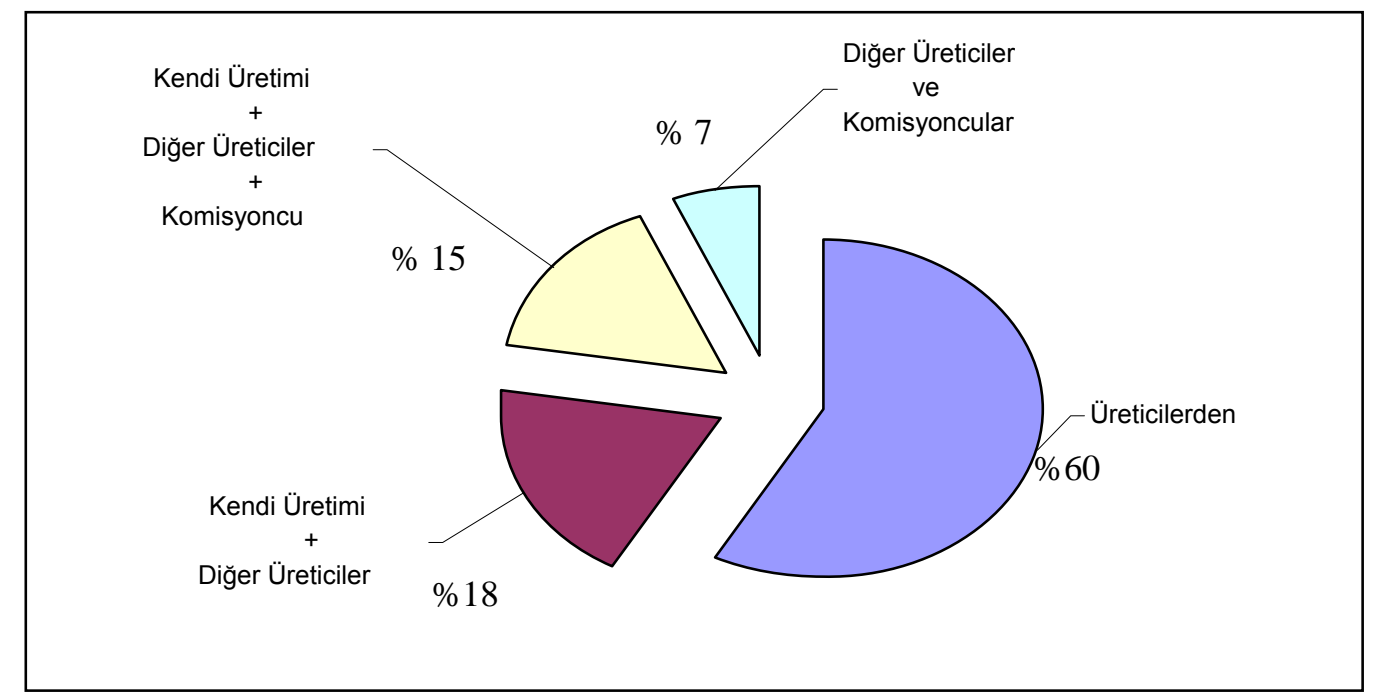

Şekil 2. Sofralık zeytin işletmelerinin zeytin tedarik şekilleri

Figure2. Olive supply figures of table olive enterprises

Zeytin işletmelerinin işledikleri zeytini önemli ölçüde Akhisar dışından (\% 87.1) zeytin alımı yaparken, \% 12.9'nun ise, sadece Akhisar'dan zeytin alımı yaptığı saptanmıştır. Akhisar dışından alım yapmakta olan işletmelerin, bu alımlarının büyük kısmını (\% 67.7) Aydın ilinden tedarik ettiği saptanmıştır. Aydın ilini sırasıyla Manisa ve Saruhanlı (\% 45.2), Bursa (\% 32.3) ve Ayvalık (\% 19.4) izlemektedir.
Zeytin işletmelerinin dolu yıldaki kapasiteleri 1338,96 ton, boş yıldaki kapasiteleri ise 982.25 ton olarak saptanmıştır. İşletmelerin dolu yıldaki çalışma gün sayıları 352 gün ve boş yıldaki çalışma gün sayıları ise 337 gün olarak saptanmıştır. İşletmelerin zeytin alımında dikkatte aldıkları kriterler likert ölçeğine göre değerlendirildiğinde, özellikle fiyat ve hasat edilme şeklinin ön plana çıktığı görülmektedir (Çizelge 1). 
Çizelge 1. İşletmeye alınan zeytinleri seçmedeki kriterlerin önemi Table 1. The level of importance in the selection criteria of olives

\begin{tabular}{|c|c|c|c|c|c|c|}
\hline \multirow{2}{*}{ Kriterler } & \multicolumn{5}{|c|}{$\%$} & \multirow{2}{*}{$\begin{array}{c}\text { Ortalama Likert Ölçek } \\
\text { Değeri(x-) }\end{array}$} \\
\hline & 1 & 2 & 3 & 4 & 5 & \\
\hline Fiyat & - & - & 9.7 & 15 & 13 & 4,32 \\
\hline Üreticiyi tanıyor olmak & 6 & 10 & 4 & 6 & - & 2 \\
\hline Zeytinin çeşidi & - & 5 & 9 & 12 & 5 & 3.54 \\
\hline Zeytinin kalibresi & - & 2 & 11 & 8 & 10 & 3,83 \\
\hline Zeytinin rengi (siyah/yeşil/pembe olması) & - & 3 & 9 & 10 & 9 & 3,80 \\
\hline Zeytinin hasat zamanı & 3 & 6 & 13 & 7 & 2 & 2,96 \\
\hline İşletmeye taşıma kolaylığının olması & 1 & 3 & 4 & 14 & 9 & 3,87 \\
\hline Üreticinin kullandığı kimyasallara dikkat ediyor olması & 1 & 6 & 14 & 2 & 8 & 3,32 \\
\hline Zeytinin hasat edilme şekli (elle/sırıkla/makine vb) & $-\mathrm{t}$ & - & 5 & 14 & 12 & 4,22 \\
\hline
\end{tabular}

1= hiç önemi yok, 2=Az Önemli, $\mathbf{3 = O r t a ~ D u ̈ z e y d e ~ O ̈ n e m l i ~} \quad \mathbf{4 = O l d u k c ̧ a ~ O ̈ n e m l i , ~} \mathbf{5 = ~ C ̧ o k ~ O ̈ n e m l i ~}$

Anket çalışmasının yapıldığı alandaki sofralık zeytin işletmelerinin \% 100'ü zeytinleri plastik kasalarda işletmeye taşımaktadırlar. İşletmeye gelen zeytinleri \% 32.3'nün bekletmeden işlemeye alındığı, \% 67,7'sinin ise işletmede bekletildiği saptanmıştır.

İsleme öncesi zeytinleri bekleten işletmelerin \% $100^{\prime u ̈ ~ i s e ~ k a p a l ı ~ a l a n l a r d a ~ u ̈ r u ̈ n u ̈ ~ b e k l e t m e k t e d i r l e r . ~}$ Kapalı alanlardaki bekletme süresi en fazla 2 -3 gün olduğu belirtilmektedir. Sofralık zeytin işletmelerinin $\%$ 37'si yeşil, \% 56' sı siyah ve \% 7'si (rengi dönük) pembe şeklinde zeytinleri işletmelerde değerlendirmektedir. Zeytin işletmelerinin tüketimi daha fazla olduğu için siyah zeytin üretimine ağırlık verdikleri görülmektedir. İşletmeler genelde oran olarak daha çok siyah zeytin işleseler de, mutlaka belli oranda yeşil zeytin de işlemektedirler.

\section{Sofralık Zeytin Üretim Masrafları}

Zeytin işletmelerinde üretim masraflarının ortaya konulması istenmişse de, veri temininde yaşanan güçlükler nedeniyle bu bölümde sınırlı ölçüde konu değerlendirilmiştir. Yapılan hesaplamalarda üretim masraflarının \%50'sinin hammadde masraflarından oluştuğu görülmektedir (Çizelge 2).

İşletmelerin \% 74.2'si ISO 9001:2000 Kalite Yönetim Sistemine, \% 35.5'i ISO 22000 Gıda Güvenliği Sistemine ve \% 25.8'i HACCP sistemine sahip olduğu saptanmıştır. Sofralık zeytin işletmelerinde ki kalite standardı bulunma oranı yüksekliği, TSE standartlarının üretim için kullanım zorunluluğundan kaynaklanmaktadır. İşletmelerin hiçbirinde ISO 14001 Çevre Yönetimi, OHSAS 18001 İşçi Sağlığı ve Güvenliği Sistemi bulunmamaktadır. Bu duruma gerekçe olarak söz konusu sistemlerin kurulması aşamasındaki danışmanlıkların ve sertifika ücretlerinin yüksek olması gösterilmiştir.
Çizelge 2. Üretim masraflarının dağılımı Table 2. The distribution of the production costs.

\begin{tabular}{lc}
\hline İşletme Masrafları & (\%) \\
\hline Hammadde (Zeytin) alımı & 50 \\
Su kullanımı & 2 \\
Kimyasal Masraflar & 8 \\
Taşıma Masrafları & 7 \\
Stok & 5 \\
Fire & 5 \\
Memur ve Daimi İşçi & 15 \\
Mevsimlik İşc Ücretleri & 1 \\
Vergi, prim vb. ödemeler & 7 \\
\hline TOPLAM & 100 \\
\hline
\end{tabular}

\section{Sofralık Zeytin Pazarlama Kanalları}

İşletmelerin \% 48.4'ü iç pazara, \% 22.6'sı dış pazara ve $\% 29^{\prime} u$ iç ve dış pazara uygun olarak ürün hazırlamaktadırlar. İşletmeler en çok iç pazara yönelik üretim yapmaktadırlar. İşletmelerinin ihracat yapma durumlarına baktığımızda, \% 61.3'nün ihracat yaptığı saptanmıştır. Yapılan görüşmelerde, işletme yöneticilerinin \% 90,3'nün mevcut üretimleri dışında yurtdışından gelecek olan talepleri karşılayabileceklerini belirtmişlerdir.

Sofralık zeytin işletmelerinin ürünlerini piyasada sunum şekillerine baktığımızda, büyük bölümünün fason üretim (\% 58.1) ve ihracatçllara doğrudan satış şeklinde olduğu (\% 58.1) görülmüştür. Bunları sırasıyla gıda toptancılarına (\% 48.4), marketlere markalı olarak $(\% 29)$, kendi satış yerinden ve marketlerde dökme (\% 9.7) satış şekillerinin izlediği saptanmıştır.

Marketlere yapılan markalı satışların ambalajlarına baktığımızda büyük kısmını tenekeler (\% 83.9) oluşturmaktadır. İkinci sırada plastik bidonlar (\% 80.6), 
üçüncü sırada polyester torbalar (\% 41.9) ve son olarak cam kavanozlarda (\% 19.4) satış olduğu saptanmıştır.

İşletmelerin sofralık zeytin pazarlamasında karşılaştıkları sorunlardan en önemlileri; kaliteli hammadde teminindeki yetersizlik ve dış pazarlardaki fiyatlarla rekabet edememeleridir. İşletmeler ürünlerini Pazarlarken özelikle alıcıların güvenilir olması ve kendileriyle uzun süreli bağlantılarının olmasına dikkat etmektedirler (Çizelge 3).

Çizelge 3. İşletmelerin alıcıları seçmede dikkate aldıkları kriterler

Table 3. The criterias taken for selecting the farmers by enterprises

\begin{tabular}{|c|c|c|c|c|c|c|}
\hline \multirow{2}{*}{ Kriterler } & \multicolumn{5}{|c|}{$\%$} & \multirow{2}{*}{ Ortalama Likert Ölçek Değeri( $x^{-}$) } \\
\hline & 1 & 2 & 3 & 4 & 5 & \\
\hline Fiyat & - & 19,35 & 22,58 & 35,48 & 22,58 & 3,61 \\
\hline Peşin ödeme olması & & 16,13 & 19,35 & 45,16 & 19,35 & 3,68 \\
\hline İstikrarlı alıcı olması & 9,68 & 3,23 & 6,45 & 48,39 & 32,26 & 3,90 \\
\hline Güvenilir olması & - & - & - & 45,16 & 54,84 & 4,55 \\
\hline
\end{tabular}

$\mathbf{1 = h i c ̧ \text { önemi yok, } \quad \mathbf { 2 = A z ~ O ̈ n e m l i , ~ } \quad 3 = O r t a ~ D u ̈ z e y d e ~ O ̈ n e m l i ~} \quad \mathbf{4 = O l d u k c ̧ a ~ O ̈ n e m l i , ~} \mathbf{5 =}$ Çok Önemli

\section{İşletme Yöneticilerin Organik Üretime Bakışları}

Görüşülen işletme yöneticilerinin gelecekte organik üretime geçme düşüncesinde olmadıkları görülmektedir. Nitekim yöneticiler, organik üretim bir alternatif pazar olarak görülmemekte ve organik üretime çok inanılmamaktadır

Yapılan bir araştırmada konvansiyonel zeytin üreticisi işletmelerin konvansiyonel tarımdan organik tarıma geçişinde etkili olabilecek faktörlere bakıldığında, ekonomik faktörlerin etkisinin daha büyük olduğu görülmektedir. Nitekim, yüksek fiyat ile ürünün pazarlanmasının kolay ve garanti olması durumunda, işletmelerin organik zeytin üretimine geçebileceği belirlenmiştir. Görüşülen konvansiyonel zeytin üreticilerine göre organik tarıma geçişte sorun yaratabilecek faktörler ise, yine ekonomik etkenlere dayanmaktadır. Nitekim işletmeler, güvenilir pazarın olmaması ve ürün fiyatının veya verilen primin yeterli olmaması durumunda, organik tarıma geçişlerinin oldukça zor olduğunu belirtmişlerdir (Olgun, vd, 2008).

Görüldüğü üzere, üreticiler ve işletmecilerin organik üretime geçmek için yüksek fiyat ve pazar garantisi beklemektedirler. Aksi halde organik üretime geçişlerinin oldukça güç olduğu saptanmıştır.

\section{Sorunlar ve Çözüm Önerileri}

Sektöre ilişkin olarak üzerinde durabilecek ilk sorun kaliteli hammadde teminidir. Sofralık zeytin işletmelerinin temelini, küçük kapasiteli çok sayıda aile işletmeleri oluşturmaktadır. Alt yapının yetersizliği, istenilen kalitede üretim yapılmasını ve verimliliği sınırlamaktadır. İşletmelerin büyük bir çoğunluğu, gerekli işletme ile ilgili yasal zorunlulukları yerine getiremediğinden kayıt dışı olarak faaliyetlerini yürütmektedirler. Bu sorunun çözülebilmesi için işletmelerin teknik ve hijyen koşullarının iyileştirilmesi ve bu konuda kontrol ve denetimlerin etkin bir şekilde yapılması gerekmektedir. Küçük işletmelerin, teknik ve hijyenik kurallara uyumunda çalışanlara eğitim verilmek üzere çalışmalar yürütülmelidir. Ayrıca, sektöre ait envanterin çıkarılması önem arz etmektedir. Bu kapsamda; yetişme alanları ve ekolojiyi de göz önünde tutup, bölgelere uygun çeşitleri yaygınlaştırabilen, Türkiye zeytinciliğinin gerçekçi bir haritası çıkarılmalıdır.

Az sayıda fakat önemli üretim kapasitesine sahip olan ve dış pazara ürün hazırlayan modern sofralık zeytin işleme tesisleri ise standart ve sürdürülebilir bir üretim için gerekli olan kaliteli hammadde temininde sorunlar yaşamaktadırlar. Kaliteli ve süreklilik gösteren hammadde teminindeki güçlükler, işlenmiş sofralık zeytin üretimini doğrudan etkilemektedir.

Ülkemizde işlenmiş sofralık zeytinde daha çok siyah Gemlik çeşidinin, tuzlu-salamura işleme tekniği önceliklidir. Bu nedenle iç pazarın tamamına yakını, ihracatın ise önemli bölümü bu çeşitten oluşmaktadır. Bu durum Türkiye'de devletin son yıllarda sertifikalı zeytin fidanı ile bahçe tesisini desteklemesi ile birlikte artmıştır. Çünkü "Gemlik" çeşidi kolay fidan üretimi nedeniyle tercih edilmektedir. Gelecek yıllarda 
işlenmiş sofralık zeytin pazarlamasında mevcut sorunların katlanarak artmaması için, bu çeşidin "Gemlik tipi" işleme dışında da değerlendirilme olanaklarının (dolgu, yeşil vb) mutlaka araştırılması gerekmektedir. Bu kapsamda bazı firmaların AR-GE çalışmaları yapmaya başlaması, dikilen fidanların geleceği açısından oldukça sevindiricidir.

Zeytinyağı üreticisine prim verildiği halde yıllardır zeytinyağının hammaddesi olan zeytine prim verilmemesi de diğer bir önemli sorundur. Bu kapsamda asıl olan zeytin tanesine prim verilmesine ilişkin çalışmalar yapılmasıdır. Böylece zeytinyağı üreticisi gibi, sofralık zeytin üreticisi de primden yararlanmalıdır.

Bir diğer sorun Coğrafi Iş̧aret eksikliğidir. Belirgin bir niteliği, ünü veya diğer özellikleriyle kökeninin bulunduğu bir yöre, alan, bölge ya da ülke ile özdeşleşmiş bir ürünü gösteren işarete "coğrafi işaret" adı verilmektedir (TPE, 2003). Bu çerçevede, zeytin ve zeytinyağında ulusal bazda korunmakta olan dört adet coğrafi işaret bulunmaktadır. Gemlik zeytini, Güney Ege zeytinyağları, Edremit Körfez Bölgesi zeytinyağları ve Ayvalık zeytinyağıdır. Ancak başta $A B$ olmak üzere, uluslararası alanda ülkemize ait herhangi bir coğrafi işaret tescilli değildir.

Diğer bir sorun AR-GE çalışmaları ve Eğitim eksikliğidir. Ülkemizde zeytin ve zeytinyağlarının yapı ve özellikleri ile ilgili yapılmış olan bilimsel çalışmaların azlığı ve düzensiz bir çerçevede yürütülmesi, Ar-Ge çalışmalarına gereken önemin verilmemesi ve bunun için ayrı bir finansal kaynağın ayrılamaması ciddi bir sorundur. Ülkemizin zeytin konusunda tek Araştırma Enstitüsü olan Zeytincilik Araştırma Enstitüsü'nün ulusal ve uluslararası projeleri yürütebilecek yeterli kalifiye elemana, araştırıcı ve mali desteğe ihtiyacı vardır.

Zeytin üreticilerini bilgilendirecek yayım çalışmalarını yürütecek; teknik eleman yetersizliği, sofralık zeytin ve zeytinyağı işleme teknolojisinde kalifiye ara eleman eksikliği ve mevcut elemanların eğitim yetersizliği diğer bir önemli sorundur. Bu kapsamda Tarım III Müdürlüklerinin eğitim ve yayım konularında daha aktif hale getirilmesi önerilebilir. Ayrıca görevli personelin araştırma kuruluşlarınca verilen hizmet içi eğitim seminerlerine katılmaları ve öğrendiklerini uygulamalı olarak üreticiye aktarmaları sağlanmalıdır. Ülkemizde teknik eleman intiyacını karşılamak amacıyla Edremit, Akhisar ve Çine'de faaliyet gösteren Zeytincilikle ilgili Meslek Yüksek Okulları desteklen- melidir. Ayrıca, Edremit'teki Zeytincilik Enstitüsü'nün sektör için fırsat olup değerlendirilmelidir.

Zeytin ve zeytinyağı üreticilerinin büyük bölümü Tarım Satış Kooperatif ve Birlikleri (TSKB) çatısı altında örgütlenmişlerdir. TSKB'ler, kendi nam ve hesaplarına üreticilerden sofralık zeytin ve zeytinyağı alımı yapmaktadırlar. TSKB'ler sofralık zeytin ve zeytinyağında güçlü birer alıcı olduklarından, bölgelerindeki ticareti canlandırmışlardır. Tariş Zeytin ve Zeytinyağı Birliği, Marmarabirlik ve Güneydoğubirlik sofralık zeytin ve zeytinyağı konusunda faaliyet gösteren tarım satış kooperatif ve birliklerindendir. Birliklerin faaliyetlerindeki etkinliklerinin artması da önemli bir konudur.

Sofralık zeytini üreten üreticiler hasat sonrasında ürünlerini ya hemen ham olarak satışa sunmaktadırlar ya da merdiven altı tabir edilen kendi aile işletmelerinde ürünlerini işleme ve uygunsuz koşullarda saklama yöntemine başvurmaktadırlar. Hasat sonrasında ürünün satışa sunulması arz fazlasının yaşandığı dönemlerde ürünlerin fiyatlarının düşmesine neden olmaktadır. Ürünlerin merdiven altı işletmelerde değerlendirilmesi ile de, ürünün kalitesinin bozulmasına neden olunmakta ve bu şeklideki ürünler genellikle kayıt dışında satılmakta ve ihracata yönlendirilememektedir. Bu durum Türkiye de Sofralık Zeytin Ürün İhtisas Borsaları ve Lisanslı Depoculuğa olan gereksinimi göstermektedir.

Ülkemizde ürün ticaretinin canlandırılması için, entegre bir şekilde borsa ve lisanslı depoculuk sistemi sisteminin birlikte çalıştırı masına ihtiyaç bulunmaktadır. Stoklama kapasitesi olmayan ve ürünlerini hasat sonrası hemen satmak istemeyen üreticiler bu sisteme göre; ürünlerini lisanslı depolara getirecek, lisanslı depolarca, ürün kalite ve standartlarına uygun olarak sınıflandırıp tartılacak ve depolanacak, ürünün teslim edildiğine ilişkin üreticiye ürün senedi verilecektir. Üretici ürün fiyatlarını düşük görüyor ve yükselmesini bekliyorsa, nakit sıkıntısı gidermek için bu senet karşılı̆ında bankalardan kredi kullanabilecek ve fiyatların uygun olduğunu düşündüğünde, ürün senedini borsaya getirip, çok sayıda alıcının ve satıcının bulunduğu bir ortamda ürününü belge üzerinden satabilecektir. Böylece sanayiciler ve spekülatörler, istedikleri kalite ve standartlarda ürünü toplu olarak bir depoda bulabilecek ve bu da belge üzerinden ürün ticaretinin gelişmesine katkıda bulunacaktır. 
Yukarıda açıklana genel nitelikli sorunlar, önemli ölçüde Akhisar ilçesi sofralık zeytin işletmeleri içinde geçerli olmakla beraber, yöreye özgü sorunlar ve çözüm önerileri ise kısaca aşağıdaki şekilde sıralanabilir:

Bölgede eski ağaçlarda domat ve uslu çeşidi ağırlıkta, az miktarda da memecik ve eşek zeytini bulunmaktadır. Son dönemlerde bölgede dikilen zeytin ağaçlarının büyük kısmı Gemlik çeşididir. Bölgenin dış ticaret açısından önemli bir potansiyel olması ve işletmelerin genelde ihracat yaptığı göz önüne alındığında bölgede daha çok dış pazar talebine uygun zeytin çeşitlerine destek verilmesi daha uygun olacaktır.

Gemlik çeşidi zeytinin gelecek yıllarda daha çok olacağı göz önüne alındığında tüm diğer bölgelerde olduğu gibi bu çeşidin "Gemlik tipi" işlemeden farkı bir yöntemle işlenmesi durumu araştırımalı ve gelecek yıllarda artarak gelen bu büyük potansiyelin değerlendirilmesi için şimdiden gerekli işleme teknikleri üzerine çalışmalar başlanmalıdır. Ayrıca dış ticarette de rağbet görebilecek ve devamlılı̆ı olabilecek talepler için uygun yeni değerlendirebilme şekilleri geliştirilmelidir.

Akhisar tarım ilçe müdürlüğü ile yapılan görüşmelere göre; geçmiş yıllardan gelen geleneksel üretim teknikleri değiştirilerek daha bilinçli bir üretim söz konusudur. Yeni zeytinlikler Gemlik çeşidi ve taban arazide olduğundan araziden maksimum verim sağlamak amaçı bilinçli zeytin tarımı yapılmaktadır. Sulama imkanı olan yerlerde sulanma oranı yarıdan fazlasına denk gelmektedir. Sulama yapılmakta ve gübreleme, yabancı ot mücadelesi ve ilaçlama yapılmaktadır. Üreticiler kullandıkları kimyasallara dikkat edilmektedir. Tarım ilaçlarında reçete sistemine geçilmesiyle üreticilerin konuya daha duyarlı olduğu bildirilmiştir.

Son zamanlarda Akhisar bölgesindeki zeytin işletmelerinin dış pazara açılmasındaki artış markalaşmanın da önemini arttırmıştır. Ancak marka tescilinin önemi işletmeler tarafından yeterinde kavranmakla beraber, halen fason üretim oranı da oldukça yüksektir. Ihracatçılara dökme şeklinde satış da oldukça yaygındır. İsletmeler marka tescilini yaptırdıktan sonra, markanın tanıtımı ve kurumsallaşması için daha profesyonel elemanlara ihtiyaç vardır. İşletmelerin dış pazarda diğer önemli sofralık zeytin üreticileriyle yarışabilmesi için, uluslararası platformlarda sektörün tanıtımını, dolayısıyla Türk zeytinin tanıtımına ağırlık verilmelidir. Sektörün belli kalitede olduğunun bilinmesi, firmalara pazarlama açısından kolaylık sağlayacaktır. Ayrıca, firmaların ürünlerini markalı olarak yurtdışına satılmasını sağlayacak ve dökme olarak satılan satışlar azalacaktır. Bu da sektörün dış pazarda da güçlü kılacak ve uluslararası platformlarda siz sahibi olup, fiyat konusunda rekabet edebilir olacaklardır.

Sofralık zeytin işletmelerinin çoğunluğu iç pazara göre ürünlerini hazırlamakla birlikte, dışarıdan gelebilecek olan ekstra talepleri karşılayabileceklerini de belirtmişlerdir. İşletmelerin daha spesifik özellikli ürünlerle ilgili çalışmalarının olmadığı da gözlenmiştir. Işletmelerin Ar-Ge çalışmalarının maliyetli olması, dolayısıyla bu tarz çalışmaları 2-3 firmanın birleşerek yürütmeleri daha uygun olacaktır. Iş̧letmelerin üretimden önce planlama yapmaları ve sadece iç piyasaya uygun ürünlere yönelmemeleri gerekmektedir.

Işletmelerin, pazarlama kanallarında karşılaştıkları sorunlarına; yeterli pazarın olmaması, aracı çokluğu ve rakip ülkelere verilen devlet desteklerinin, ülkemize göre daha yüksek olması, ürünlerin dış pazardaki müşterilerin talebini karşılamaması eklenebilir.

Zeytin ve Zeytinyağı konusunda isabetli olarak saptanmış politikaların oluşturulması ve yürütülmesi ülke genelinde olduğu gibi, araştırma alanı için de sorunların çözümünde önemli bir araç olarak öne çıkmaktadır.

\section{SONUÇ}

Sofralık zeytin işletmeleri (salamurhaneler) genellikle küçük aile tipi işletmelerden oluşmaktadır. Bu işletmelerde teknik ve hijyenik alt yapı yetersizlikleri ve büyük bir çoğunluğunun gerekli işletme ile ilgili yasal zorunlulukları yerine getiremediğinden, kayıt dışı olarak faaliyetlerini yürütmektedirler. Işletmelerin teknik ve hijyen koşullarının iyileştirilmesi ve bu konuda kontrol ve denetimlerin ilgili kuruluşlarca etkin bir şekilde yapılması gerekmektedir.

Önemli üretim kapasitesine sahip olan ve dış pazara ürün hazırlayan modern sofralık zeytin işleme tesisleri, standart, sürdürülebilir bir üretim için gerekli olan kaliteli hammadde temininde sıkıntılarla karşılaşmaktadırlar. Sürdürülebilir üretim, sürekli hammadde teminiyle mümkün olacaktır. Kaliteli hammadde temininde de, uygulanmakta olan tarımın, işleme şeklinin ve stoklamanın büyük önemi vardır. Ayrıca zeytin tanesine prim verilmesine ilişkin çalışmalar 
yapılarak, sofralık zeytin üreticisi de primden yararlanmalıdır.

İç ve dış pazarın talepleri doğrultusunda çeşitliliğin olmaması, bir pazarlama sorunu olarak ortaya çıkmaktadır. İri kalibre, tuzsuz, farklı tatlandııımış ürünlere ait işleme yöntemlerinin ve buna uygun çeşitlerin olmaması, bu sorunların kaynağını teşkil etmektedir. Ülkemiz sofralık zeytin üretimi, başta Gemlik çeşidi ile yapılan tuzlu, salamura üretim teknolojisine dayanmakta olup, iç pazarın tamamına yakın kısmı ile ihracatımızın önemli bir bölümü bu ürünlerden oluşmaktadır.

\section{KAYNAKLAR}

Anonim, 2009, Akhisar İlçe Tarım Müdürlüğü Verileri, Akhisar/Manisa.

Anonim, 2010, Akhisar Ticaret ve Sanayi Odası Verileri (ATSO), Akhisar/Manisa

FAO, 2014,http://faostat,fao.org.

Gıda Tarım ve Hayvancılık Bakanlığı,2014, Türkiye'de Tarım Alanları, Bitkisel Üretim Genel Müdürlüğü .Broşür.

Gümrük ve Ticaret Bakanlığı,2014, 2013 Zeytin ve Zeytinyağı Raporu, Kooperatifçilik Genel Müdürlüğü, Şubat,2014.

Güner B., Boyraz Z. , Çitçi, M.D., 2010, Tütüncülükten Zeytinciliğe Geçiş Akhisar Örneği”, http://www.zeytinportali.com/article/263/tutunculuktenzeytincilige-gecis-akhisar- manisa-ornegi-2.aspx) (Erişim tarihi: 03.06.2010).

Kayalı, A. C., Tokmakoğlu, U., Sesli, M., Kayalı, N. T., 2008, Development Potential of Olive Production Establishments in Akhisar-Manisa-Turkey. Asian Journal of Scientific Research, 1 (2), s. 103-112. http://docsdrive.com/pdfs/ansinet/ajsr/2008/103112.pdf, (Erişim tarihi: 01.02.2010).

Newbold, P., 1995, Statistics for Business and Economics, PrenticeHall, New Jersey.

Olgun, A., Artukoğlu, M. M. ve Adanacıŏlu,H., 2008, Konvansiyonel Zeytin Üreticilerinin Organik Zeytin Üretimine Geçme Konusundaki Eğilimleri Üzerine Bir Araştırma, Ege Üniversitesi Ziraat Fakültesi Dergisi., 2008, 45 (2): 95-101 ISSN 1018 - 8851, İzmir, 98-101s.
Her üreticinin farklı üretim şekillerini kullanması, ürün standardı sorununu oluşturmakta, sürekli ve standart üretimin oluşturulması, ortak üretim yapmakla mümkün olabilir. Bu amaçla üretici birlikleri ya da sofralık zeytin stoklama ve işleme ihtisas depoculuğunu hayata geçirilmelidir.

Ülkemiz sofralık siyah ve yeşil zeytinde ürün işleme çeşitliliği artırılarak yeni, pazarların bulunması gerekmekte ve sofralık zeytin üretiminde mevcut zeytin çeşitlerimizin özellikle de Gemlik çeşidinin Gemlik tipi işleme dışında da değerlendirilme olanaklarının (dolgu, yeşil vb.) araştııılması gerekmektedir.

Özkaya, M. T., Tunalığlu, R. ve Eken, Ş., 2010, Türkiye Zeytinciliğinin Sorunları ve Çözüm Önerileri, TMMOB Ziraat Mühendisleri Odası, Ziraat Mühendisliği VII. Teknik Kongresi, 11-15 Ocak, Ankara, 515-537s.

Özkaya,M.T., Tunalığlu; R., Özkaya,F.D., Ulaş, M., 2015, Zeytin Üretiminde Değişimler ve Yeni Arayışlar, TMMOB Ziraat Mühendisleri Odası, Ziraat Mühendisliği VIII. Teknik Kongresi, 12-16 Ocak 2015, Ankara,630-644s.

Türk Patent Enstitüsü (TPE), 2003, Coğrafi İşaretler, Türk Patent Enstitüsü Yayını, Ankara.

Türkiye Büyük Millet Meclisi (TBMM), 2008, Zeytin ve Zeytinyağı ile Diğer Bitkisel Yağların Üretiminde ve Ticaretinde Yaşanan Sorunların Araştırılarak Alınması Gereken Önlemlerin Belirlenmesi Amacıyla Kurulan Meclis Araştırma Komisyonu Raporu, 23.Dönem, Ankara, www.tbmm.gov.tr/sirasayi/donem23/yil01/ss29pdf, (Erişim tarihi: 02.07.2010),120-130-296s.

UZK, 2014, International Olive Council, 14th meeting of the Economic Committee, Madrid, Nov.2014.

Ulusal Zeytin ve Zeytinyağı Konseyi (UZZK), 2010, http://www.zeytinportali.com/article/220/uzk-ulke-raporlariturkiyede-zeytin-yetistiriciligi-2.aspx, (Erişim tarihi: 29.11.2010).

ZZTK,2015, Zeytin ve Zeytinyağı Tanıtım Komitesi ,zztk.org.tr (Erişim 09.02.2105). 